\title{
Discrepancies between the internet and academic literature regarding vitamin use for male infertility
}

\author{
Mary K. Samplaski ${ }^{1}$, Chase G. Clemesha ${ }^{2}$ \\ ${ }^{1}$ Institute of Urology, ${ }^{2}$ Keck School of Medicine, University of Southern California, Los Angeles, CA, USA \\ Contributions: (I) Conception and design: All authors; (II) Administrative support: None; (III) Provision of study material or patients: None; (IV) \\ Collection and assembly of data: All authors; (V) Data analysis and interpretation: All authors; (VI) Manuscript writing: All authors; (VII) Final \\ approval of manuscript: All authors. \\ Correspondence to: Mary K. Samplaski, MD. Institute of Urology, University of Southern California, 1441 Eastlake Ave, Suite 7416, Los Angeles, CA \\ 90089-9178, USA. Email: mary.samplaski@med.usc.edu.
}

Background: The accuracy of online medical information is variable. A 2014 Cochrane review did not
support a robust improvement in male infertility after antioxidant supplementation. Many subfertile men
take vitamins in hopes of improving their fertility. We sought to evaluate the content of online information
for male fertility vitamins, and compare this with the published literature.
Methods: We searched Google to assess online information regarding vitamins and male infertility.
Websites were evaluated for authorship, content, claims and validity. We then reviewed the Recommended
Daily Allowance and upper tolerable intake level for each vitamin, and compared this with the supplements
actual content.

Results: Four websites were posted by an academic source, 7 private clinic, 31 industry, 8 were patient blogs and 50 other sources. Reproductive claims made by websites included: Improved sperm count: 65; improved pregnancy rates: 42; improved live birth rates: 9; healthier offspring: 18. Overall, 76 websites claimed some improvement in semen parameters; 85 claimed some improved reproductive outcome. 26 websites were supported by peer-reviewed literature. None of the supplements had more than the upper tolerable intake level of any of the vitamins, but several were over the RDA, most commonly zinc, vitamin B12 and selenium.

Conclusions: Many websites claim improvements in a variety of male reproductive outcomes after vitamin supplementation. These are often not supported by the medical literature. We need to provide evidencebased information to patients so that they can have realistic expectations of the benefits that vitamins may have on male reproductive outcomes.

Keywords: Antioxidants; internet; male infertility; sperm; vitamins

Submitted Apr 18, 2018. Accepted for publication Apr 23, 2018.

doi: 10.21037/tau.2018.05.01

View this article at: http://dx.doi.org/10.21037/tau.2018.05.01

\section{Introduction}

Approximately $30-80 \%$ of male subfertility is thought to be in part due to the negative effects of oxidative stress on sperm (1). Oxidative stress occurs when reactive oxygen species (ROS) overwhelm the semen's innate antioxidant defenses $(1,2)$. While sperm themselves have relatively low levels of antioxidants and DNA repair enzymes, the seminal plasma provides an additional supply of these (3). "Antioxidants" found in semen include both enzymes and non-enzymatic substances, which interact synergistically to ensure optimal protection against ROS (2). Antioxidants naturally found in seminal fluid include vitamins A, E, C, and $\mathrm{B}$ complex, glutathione, pantothenic acid, coenzyme Q10, carnitine, folate, zinc, selenium, copper, carnitine and carotenoids $(2,4)$. These antioxidants scavenge free radicals 
to help to overcome ROS $(4,5)$.

A multitude of studies have looked at the effects of various combinations of vitamins and their effects on semen parameters and reproductive outcomes. These have had conflicting results. Some trials show a benefit for antioxidant supplementation in treating male subfertility, while others do not show this benefit (6). A 2014 Cochrane review (7) looked at the effects of oral antioxidant supplementation on subfertile male partners in couples seeking fertility assistance. The results of this review did not support a robust improvement in male infertility after antioxidant supplementation. "Low-quality evidence" from four small randomized controlled trials (RCTs) found that antioxidants may increase live birth rates in couples attending fertility clinics. Similarly, "low-quality evidence" from seven RCTs found that antioxidant supplementation may improve clinical pregnancy rates. "Very low-quality evidence" found that antioxidant supplementation may lower miscarriage rates. This highlights the poor quality of available data that is available for the use of antioxidants in male infertility.

Approximately $50 \%$ of American adults consume dietary supplements to promote overall health and fill dietary gaps $(8,9)$. Many subfertile men are advised to take dietary antioxidant supplements in hopes of improving their fertility. It is important that these men have access to information that is evidence-based and will give them a realistic picture of what they can hope to see after antioxidant supplementation. Too often, these couples seem to believe that vitamins will "cure" their infertility, when there is minimal evidence to support this. This is not only giving them unrealistic hopes, but also potentially delaying inevitable fertility treatments which may be dependent on female age.

We know that our patients utilize the Internet for medical information (10-13). People ages 20-45 years have been shown to use the Internet as a source of health information more frequently than their older counterparts (14). This group represents patients in their reproductive years, which would suggest that patients would likely look to the Internet for information on reproductive medical conditions. Anecdotally, many physicians have had patients refer to information that they found using "Dr. Google". At times this information is completely unsupported by the medical or scientific literature (15). The purpose of this study was to determine if claims made by online websites regarding the effects of vitamin and antioxidant supplementation on male infertility, are supported by the medical literature.

\section{Methods}

We searched Google to assess the information that is presently available online regarding vitamins and male infertility. We chose Google because it is the most widely used search engine, comprising $74.5 \%$ of Internet searches (16). The search terms used were "vitamins and sperm". The top 100 sites were reviewed. Websites were evaluated for authorship, content and validity.

Websites were categorized into several broad categories for authorship: (I) hospital or academic institution; (II) private clinic/physician; (III) industry/manufacturer; (IV) patient blogs or online forums; (V) other. We also evaluated websites for who wrote the articles; MD (and type), journalist, patient or no author stated.

The content and validity/quality of information were assessed by grouping the websites into the following categories: (I) claims of improved sperm count; (II) claims of improved sperm motility; (III) claims of improved sperm morphology; (IV) claims of improved pregnancy rates; (V) claims of improved live birth rates; (VI) claims of healthier offspring. Websites were also surveyed for mention of risks of taking vitamins/supplements, and if there was a discussion of the mechanism of action for vitamins potential impact on male fertility. Finally, websites were reviewed for references (peer-reviewed literature to support any scientific or objective claims made).

We then reviewed the FDA Recommended Daily Allowance (RDA) for each of the vitamins contained in these supplements, as well as the upper tolerable intake level (UL) as set by the Institute of Medicine of the National Academy of Science (17) and compared this with the vitamins stated content.

Our institution's human subjects' research review board granted an exemption of this study from further review.

\section{Results}

The total number of results generated using the search term "vitamins and sperm" was 2.94 million. To ensure an adequate sample, the first 100 websites were reviewed. Of these, 4 were posted by an academic hospital or source, 7 were posted by a private clinic, 31 were posted by industry, 8 were patient blogs, and 50 were classified as "other". Of the "other" group, 10 pages were on websites with information on fertility or 'achieving a pregnancy', 8 pages were on men's health websites, 5 were on natural health websites, 4 were on websites with information on 
achieving a pregnancy by natural means, 7 were on general medical information or healthy living websites, 1 was on a miscarriage website, 1 was on a testosterone information website; 1 was on a sperm information website; 1 was on a nursing information website, 1 was on Web-MD, 1 was on Wiki-how, and 10 were on general news or science news websites as a single article. Of the 4 websites with academic authors, 2 linked directly to full-length, peer-reviewed articles, written by MDs, the 3rd linked to a research lab presenting its work, the 4th was written by a urologist specializing in male infertility. Of the 7 websites authored by a private clinic, 3 were authored by MDs, 1 by a urologist specializing in male infertility, 1 by a Naturopathic physician, and 1 by a Reproductive Gynecologist. Only 2 of the 31 websites posted by industry claimed an author, one by a Naturopathic physician and one by a $\mathrm{PhD}$ (the site did not state in what). For the 8 blog websites, 1 was authored by a urologist specializing in male infertility, 1 by a Professor (the site did not state in what), and the remaining 6 by patients with no medical professional input. Of the 50 "other" websites, 7 were authored by MDs, including 1 Family Medicine physician, 1 Complementary and Integrative Medicine physician. The remainder did not specify what type of physician had authored them.

Claims made by websites regarding the effect of vitamins on male fertility included: improved sperm count in 65 ( 1 academic, 4 private clinic, 19 industry, 5 patient blog, 36 other); improved sperm motility in 71 ( 2 academic, 5 private clinic, 25 industry, 5 patient blog, 34 other); improved sperm normal morphology in 49 ( 1 academic, 2 private clinic, 17 industry, 5 patient blog, 24 other); improved pregnancy rates in 42 (3 academic, 3 private clinic, 14 industry, 3 patient blog, 19 other); improved live birth rates in 9 ( 1 academic, 1 private clinic, 2 industry, 0 patient blog, 5 other); healthier offspring in 18 (1 academic, 1 private clinic, 3 industry, 1 patient blog, 12 other). Overall, 76 websites claimed some type of improvement in semen parameters. Eighty-five websites claimed some type of improved reproductive outcome.

Fifteen websites mentioned the risks of taking vitamins ( 0 academic, 2 private clinic, 4 industry, 3 patient blog, 6 other). The risks stated were: unspecified selenium toxicity at high doses, diabetes triggered by selenium, headaches, hair loss, loss of finger nails sperm damage when high doses of vitamins $\mathrm{C}$ and $\mathrm{E}$ are combined, interactions of vitamin $\mathrm{E}$ with anti-clotting drugs, heartburn, general warnings to avoid overdose, general zinc toxicity, renal calculi and possible unspecified interactions with other medications.
Fifteen websites mentioned the mechanism of action of vitamins ( 0 academic, 1 private clinic, 5 industry, 3 patient blog, 6 other). The stated mechanisms of action were primarily related to antioxidant effects of vitamins, but also included "preventing sperm clumping", "increasing sex hormone levels", "signaling through vitamin D", "increasing energy in sperm", "increasing proliferation of sperm", "promoting protein absorption in the testes", "preventing genetic breakdown", "reversing DNA damage", "increasing homocysteine" and "increasing DNA replication". Twenty-six websites referenced peer-reviewed literature (3 academic, 1 private clinic, 6 industry, 1 patient blog, 15 other). The content of these pages were reviewed, and for all of the pages with peer-reviewed references, the claims made were supported by the cited literature. Twentyone websites mentioned if trade vitamins were better than generic (1 private clinic, 14 industry, 6 other). Seventy two of the websites contained advertisements (4 private clinic, 26 industry, 5 patient blog, 37 other) and 38 had links to purchase vitamins ( 2 private clinic, 21 industry, 1 patient blog, 14 other).

We then looked at the components of 20 male fertility vitamins. We surveyed the FDA RDA for each of these, as well as the UL (17) (online: http://tau.amegroups. com/public/system/tau/tau.2018.05.01-1.pdf). One of the supplements contained 1 vitamin, 2 supplements contained 2 vitamins, 2 contained 3 vitamins, 1 contained 6 vitamins, 4 contained 7 vitamins, 1 contained 9 vitamins, 1 contained 12 vitamins, 1 contained 13 vitamins, 1 contained 18 vitamins, 1 contained 19 vitamins, 1 contained 20 vitamins, 3 contained 21 vitamins and 1 contained 22 vitamins. The most common vitamins contained in these supplements were: zinc (18), vitamin E (17), folic acid (16), vitamin C (15) and selenium (15).

Of the supplements studied, 14 had less than the RDA for at least 1 of the vitamins included. None of supplements had more than the UL of any of the vitamins, but several were over the RDA. The most commonly oversupplemented vitamins were zinc (16), vitamin B12 (11) and selenium (11). For zinc the mean supra-RDA supplement dose was $24.5 \mathrm{mcg}$, or $2.2 \times$ the RDA. For vitamin B12 the mean supra-RDA supplement dose was $114.9 \mathrm{mcg}$, or $47.9 \times$ the RDA. For selenium the mean supra-RDA supplement dose was $116.4 \mathrm{mcg}$, or $2.1 \times$ the RDA.

\section{Discussion}

Subfertile men have been shown to have higher levels of 
ROS as compared with fertile men (3). Because of this, a multitude of studies have been done looking at the effects of various combinations of vitamins and their effects on semen parameters and reproductive outcomes. These have had conflicting results, and some data show a benefit for antioxidant supplementation in treating male subfertility, but others do not (6). This is likely because of variation in antioxidant doses and combinations, as well as individual patient baseline lifestyle and dietary factors. In addition, for most of these oral antioxidant supplements, data does not exist on absorption or their presence in the male reproductive tract (18). This is not addressing any female factors, which may ultimately effect pregnancy and live birth rates. Finally, most of the available studies are limited by small numbers of men and no homogenous target population, as well as a lack of randomized data (2).

We know that our patients utilize the internet for medical information (10-13), particularly during the reproductive years (14). Therefore, it is reasonable to believe that these patients seek information on reproductive conditions on the Internet. The concept of "Dr. Google" is familiar to many physicians. When the accessed website is a reputable source, the information found online may be of high quality, and may enhance patient knowledge. However, the lack of regulation for what is posted makes it difficult for patients to know what information they can trust and what is not valid. At times, website claims are completely unsupported by the medical or scientific literature (15). There are some patients who take what they read on the Internet as fact, and it is important for medical providers to provide them with accurate information either during clinic visits or via the Internet.

A 2014 Cochrane review (7) looked at the effects of oral antioxidant supplementation on subfertile male partners in couples seeking fertility assistance. The results of this review did not support a robust improvement in male infertility after antioxidant supplementation. "Low-quality evidence" from four small RCTs found that antioxidants may increase live birth rates in couples attending fertility clinics. Similarly, "low-quality evidence" from seven RCTs found that antioxidant supplementation may improve clinical pregnancy rates. "Very low-quality evidence" found that antioxidant supplementation may lower miscarriage rates.

We found that the available online literature makes many unsupported claims for the effects of vitamins on male infertility. Sixty-five websites claimed that vitamins would improve sperm counts, 71 claimed improved sperm motility,
49 claimed improved sperm normal morphology. In addition to unsupported claims in semen parameters, websites overpromised regarding other fertility outcomes. Forty-two claimed that the use of vitamins improved pregnancy rates, 9 improved live birth rates in 9 , and 18 healthier offspring in 18. These are in direct contrast to the findings of the 2014 Cochrane review (7). This emphasizes the need for evidence-based information on the use of antioxidants for male factor infertility on the Internet. Reassuringly, while only 26 websites referenced peer-reviewed literature, the content of these pages was supported by the cited literature.

We found that only 15 websites surveyed mentioned risks of taking vitamins. While an excess of many of these supplements may have adverse health effects, it is reassuring that none of the vitamins were present in doses greater than recommended by the FDA (17). What is concerning is that 14 had less than the RDA for at least 1 of the vitamins included. While men may get the vitamins that they need from a healthy diet, it is surprising that these are not found in supplements targeted at male infertility.

Limitations of our study are that there may be regional and geographic differences in search engine results. We chose Google as our search engine because it is the most commonly used search engine (16), however, the addition of other search engines (Yahoo or Bing) may have yielded different results. However, in spite of these limitations, our data clearly demonstrates the unrealistic expectations that are stated online for the role of vitamins and antioxidants in male infertility. This highlights the need for evidence-based patient education materials relating to this topic.

In conclusion, many websites claim improvements in a variety of male reproductive outcomes after vitamin supplementation, ranging from semen parameters to offspring outcomes. Overall, 76 websites claimed some type of improvement in semen parameters and 85 websites claimed some type of improved reproductive outcome. These claims are often not supported by the medical literature. Reassuringly, none of the supplements we surveyed had greater than the FDA UL for any individual vitamin. We need to provide evidence-based information to patients, so that they can have realistic expectations of the benefits that vitamins may have on male reproductive outcomes.

\section{Acknowledgements}

None. 


\section{Footnote}

Conflicts of Interest: The authors have no conflicts of interest to declare.

\section{References}

1. Tremellen K. Oxidative stress and male infertility--a clinical perspective. Hum Reprod Update 2008;14:243-58.

2. Walczak-Jedrzejowska R, Wolski JK, Slowikowska-Hilczer $\mathrm{J}$. The role of oxidative stress and antioxidants in male fertility. Cent European J Urol 2013;66:60-7.

3. Aktan G, Dogru-Abbasoglu S, Kucukgergin C, et al. Mystery of idiopathic male infertility: is oxidative stress an actual risk? Fertil Steril 2013;99:1211-5.

4. Talevi R, Barbato V, Fiorentino I, et al. Protective effects of in vitro treatment with zinc, d-aspartate and coenzyme q10 on human sperm motility, lipid peroxidation and DNA fragmentation. Reprod Biol Endocrinol 2013;11:81.

5. Zini A, Al-Hathal N. Antioxidant therapy in male infertility: fact or fiction? Asian J Androl 2011;13:374-81.

6. Agarwal A, Allamaneni SS. The effect of sperm DNA damage on assisted reproduction outcomes. A review. Minerva Ginecol 2004;56:235-45.

7. Showell MG, Mackenzie-Proctor R, Brown J, et al. Antioxidants for male subfertility. Cochrane Database Syst Rev 2014;(12):CD007411.

8. Bailey RL, Gahche JJ, Thomas PR, et al. Why US children use dietary supplements. Pediatr Res 2013;74:737-41.

9. Dickinson A, Blatman J, El-Dash N, et al. Consumer usage and reasons for using dietary supplements: report of a series of surveys. J Am Coll Nutr 2014;33:176-82.

10. Samanci Y, Celik SE. Low Back Pain and Internet: Infopollution. Turk Neurosurg 2017;27:804-8.

11. Park SY, Go E. Health information seeking on the Internet: The role of involvement in searching for and assessing online health information. Health Mark Q 2016;33:327-41.

12. Hermes ED, Merrel J, Clayton A, et al. Computer-based

Cite this article as: Samplaski MK, Clemesha CG. Discrepancies between the internet and academic literature regarding vitamin use for male infertility. Transl Androl Urol 2018;7(Suppl 2):S193-S197. doi: 10.21037/tau.2018.05.01 self-help therapy: A qualitative analysis of attrition. Health Informatics J 2016:1460458216683536. [Epub ahead of print].

13. Hirsch M, Aggarwal S, Barker C, et al. Googling endometriosis: a systematic review of information available on the Internet. Am J Obstet Gynecol 2017;216:451-458.e1.

14. Rahmqvist $M$, Bara AC. Patients retrieving additional information via the Internet: a trend analysis in a Swedish population, 2000-05. Scand J Public Health 2007;35:533-9.

15. Abel GA, Cronin AM, Earles K, et al. Accessibility and Quality of Online Cancer-Related Clinical Trial Information for Naive Searchers. Cancer Epidemiol Biomarkers Prev 2015;24:1629-31.

16. NetMarketShare. Market Share Statistics for Internet Technologies. 2017. Available online: https:// netmarketshare.com/search-engine-market-share.as px?options=\%7B $\% 22$ filter $\% 22 \% 3 \mathrm{~A} \% 7 \mathrm{~B} \% 22 \% 24 \mathrm{a}$ nd\%22\%3A\%5B\%7B\%22deviceType \%22\%3A\%7B \%22\%24in\%22\%3A\%5B\%22Desktop\%2Flaptop\% 22\%5D\%7D\%7D\%5D\%7D\%2C\%22dateLabel\% $22 \% 3 \mathrm{~A} \% 22$ Trend $\% 22 \% 2 \mathrm{C} \% 22$ attributes $\% 22 \% 3 \mathrm{~A}$ \%22share\%22\%2C\%22group $\% 22 \% 3 \mathrm{~A} \% 22$ searchE ngine $\% 22 \% 2 \mathrm{C} \% 22$ sort $\% 22 \% 3 \mathrm{~A} \% 7 \mathrm{~B} \% 22$ share $\% 2$ 2\%3A-1\%7D\%2C\%22id\%22\%3A\%22searchEngin esDesktop $\% 22 \% 2 \mathrm{C} \% 22$ dateInterval $\% 22 \% 3 \mathrm{~A} \% 22$ Monthly\%22\%2C\%22dateStart\%22\%3A\%222017$01 \% 22 \% 2 \mathrm{C} \% 22$ dateEnd $\% 22 \% 3 \mathrm{~A} \% 222017-$ $12 \% 22 \% 2 \mathrm{C} \% 22$ segments $\% 22 \% 3 \mathrm{~A} \% 22-1000 \% 22 \% 7 \mathrm{D}$, accessed January 8, 2018.

17. Supplements NOoD. Nutrient Recommendations: Dietary Reference Intakes (DRI). 2018. Available online: https:// ods.od.nih.gov/Health_Information/Dietary_Reference_ Intakes.aspx, accessed January 19, 2018.

18. Zini A, San Gabriel M, Baazeem A. Antioxidants and sperm DNA damage: a clinical perspective. J Assist Reprod Genet 2009;26:427-32. 
Table 1 Male fertility vitamins stated content and the corresponding FDA RDA and UL

\begin{tabular}{|c|c|c|c|c|c|c|c|c|c|c|c|c|c|c|c|c|c|c|c|c|c|c|}
\hline \multirow[b]{2}{*}{ Vitamin } & \multirow[b]{2}{*}{ RDA } & \multirow[b]{2}{*}{ uL } & \multicolumn{20}{|c|}{ Male fertility vitamins stated content } \\
\hline & & & ConceptionXR ${ }^{\circ}$ & $\begin{array}{l}\text { Fertitity } \\
\text { Blend" }\end{array}$ & FertiliAd ${ }^{\circ}$ & $\begin{array}{l}\begin{array}{l}\text { The male } \\
\text { prenatale }\end{array} \\
\text { a }\end{array}$ & $\begin{array}{l}\text { One-A-Day pre-- } \\
\text { pregnancy pack }\end{array}$ & Pro creation" & Menevit & $\begin{array}{l}\text { GNC Men's } \\
\text { ArginMax" }\end{array}$ & Evolution $60^{\circ}$ & $\begin{array}{c}\text { Fertility smart- } \\
\text { conceive for men }\end{array}$ & 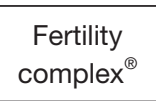 & Conceive plus ${ }^{\otimes}$ & $\begin{array}{l}\text { Dr. Axe: men's } \\
\text { fermented multit }\end{array}$ & $\begin{array}{l}\text { BioXgenic power } \\
\text { finish }^{\circ}\end{array}$ & $\begin{array}{l}\text { Rainbow } \\
\text { light men's } s^{\circ}\end{array}$ & $\begin{array}{l}\text { Sexual vitality for } \\
\text { men }^{8}\end{array}$ & Semenax" & $\begin{array}{l}\text { Fertile } \\
\text { male }^{\circ}\end{array}$ & Wellman conception ${ }^{\oplus}$ & $\begin{array}{c}\text { P2i baby } \\
\text { pre-conception }\end{array}$ \\
\hline Boron & NE & NE & - & - & - & - & - & - & - & - & - & - & - & - & - & - & $1 \mathrm{mcg}$ & - & - & - & - & $500 \mathrm{mcg}$ \\
\hline Calcium & $1,000 \mathrm{mg}$ & $2,500 \mathrm{mg}$ & - & - & - & - & $260 \mathrm{mg}^{+}$ & $50 \mathrm{mg}^{+}$ & - & - & - & - & - & - & $3 \mathrm{mg}^{+}$ & - & $50 \mathrm{mg}^{+}$ & $60 \mathrm{mg}^{+}$ & - & - & - & $100 \mathrm{mg}^{+}$ \\
\hline Chromium & $35 \mathrm{mcg}$ & NE & - & - & $120 \mathrm{mcg}$ & - & $35 \mathrm{mcg}$ & $120 \mathrm{mcg}$ & - & - & - & - & - & - & $40 \mathrm{mcg}$ & - & $200 \mathrm{mcg}$ & - & - & - & $50 \mathrm{mcg}$ & $120 \mathrm{mcg}$ \\
\hline Copper & $900 \mathrm{mcg}$ & $10,000 \mathrm{mcg}$ & - & - & $2 \mathrm{mg}$ & - & $0.9 \mathrm{mg}$ & $2 \mathrm{mg}$ & - & - & - & - & - & - & - & - & $1 \mathrm{mg}$ & $1 \mathrm{mg}$ & - & $1 \mathrm{mg}$ & 1,000 mcg & - \\
\hline Folic acid & $400 \mathrm{mcg}$ & 1,000 mcg & $1,000 \mathrm{mcg}$ & $400 \mathrm{mcg}$ & $500 \mathrm{mcg}$ & 1,000 mcg & $500 \mathrm{mcg}$ & $800 \mathrm{mcg}$ & $500 \mathrm{mcg}$ & $400 \mathrm{mcg}$ & $400 \mathrm{mcg}$ & $400 \mathrm{mg}$ & $400 \mathrm{mcg}$ & $400 \mathrm{mcg}$ & $70 \mathrm{mcg}^{+}$ & - & - & $800 \mathrm{mg}$ & - & - & $400 \mathrm{mcg}$ & $800 \mathrm{mcg}$ \\
\hline Iodine & $150 \mathrm{mcg}$ & $1,100 \mathrm{mcg}$ & - & - & $150 \mathrm{mcg}$ & - & $150 \mathrm{mcg}$ & - & - & - & - & - & - & - & - & - & - & - & - & - & - & $150 \mathrm{mcg}$ \\
\hline Iron & $8 \mathrm{mg}$ & $45 \mathrm{mg}$ & - & - & - & - & - & $18 \mathrm{mg}$ & - & - & - & - & - & $5 \mathrm{mg}^{+}$ & $58 \mathrm{mcg}$ & - & - & - & - & - & $6 \mathrm{mg}^{+}$ & $5 \mathrm{mg}^{\dagger}$ \\
\hline Lycopene & NE & $\mathrm{NE}$ & $10 \mathrm{mg}$ & - & - & - & $6 \mathrm{mg}$ & - & $6 \mathrm{mg}$ & - & - & - & - & - & - & - & - & - & - & - & - & - \\
\hline Magnesium & $320 \mathrm{mg}$ & $420 \mathrm{mg}$ & - & - & $120 \mathrm{mg}^{+}$ & - & $140 \mathrm{mg}^{+}$ & $25 \mathrm{mg}^{+}$ & - & - & - & - & - & $56.25 \mathrm{mg}^{+}$ & $1 \mathrm{mg}^{+}$ & - & $100 \mathrm{mg}^{+}$ & - & - & - & $60 \mathrm{mg}^{+}$ & $100 \mathrm{mg}^{\dagger}$ \\
\hline Manganese & $2.3 \mathrm{mg}$ & $11 \mathrm{mg}$ & - & - & $2 \mathrm{mg}^{+}$ & - & $2.3 \mathrm{mg}$ & $5 \mathrm{mg}$ & - & - & - & - & - & - & $1 \mathrm{mg}^{+}$ & - & $2 \mathrm{mg}^{+}$ & - & - & - & $0.5 \mathrm{mg}^{+}$ & $2 \mathrm{mg}^{\dagger}$ \\
\hline Molybdenum & $45 \mathrm{mcg}$ & $2,000 \mathrm{mcg}$ & - & - & - & - & - & - & - & - & - & - & - & - & $80 \mathrm{mcg}$ & - & $75 \mathrm{mcg}$ & - & - & - & - & $75 \mathrm{mcg}$ \\
\hline Selenium & $55 \mathrm{mcg}$ & $400 \mathrm{mcg}$ & $200 \mathrm{mcg}$ & $70 \mathrm{mcg}$ & $100 \mathrm{mcg}$ & $50 \mathrm{mcg}^{+}$ & $55 \mathrm{mcg}$ & $70 \mathrm{mcg}$ & $26 \mathrm{mcg}^{+}$ & $70 \mathrm{mcg}$ & $100 \mathrm{mcg}$ & $140 \mathrm{mcg}$ & - & $55 \mathrm{mcg}$ & $80 \mathrm{mcg}$ & - & $200 \mathrm{mcg}$ & - & - & - & $150 \mathrm{mcg}$ & $100 \mathrm{mcg}$ \\
\hline Vitamin A & 1,000 IU & 10,000 & - & - & 5,000 II & 5,000 IU & $810 \mathrm{mcg}$ & 5,000 & - & $550 \mathrm{IU}^{+}$ & - & - & - & $1 \mathrm{mg}$ & $500 \mathrm{IU}^{+}$ & - & 5,000 II & - & - & - & 2500 & 5,000 II \\
\hline Vitamin B1 & $1.2 \mathrm{mg}$ & NE & - & - & $1.5 \mathrm{mg}$ & - & $1.2 \mathrm{mg}$ & $20 \mathrm{mg}$ & - & $1.5 \mathrm{mg}$ & - & - & - & - & $2 \mathrm{mg}$ & - & $25 \mathrm{mg}$ & - & - & - & $12 \mathrm{mg}$ & $6 \mathrm{mg}$ \\
\hline Vitamin B12 & $2.4 \mathrm{mcg}$ & $\mathrm{NE}$ & - & $6 \mathrm{mcg}$ & $25 \mathrm{mcg}$ & $15 \mathrm{mcg}$ & $2.4 \mathrm{mcg}$ & $20 \mathrm{mcg}$ & - & $6 \mathrm{mcg}$ & - & $6 \mathrm{mcg}$ & - & $6 \mathrm{mcg}$ & $55 \mathrm{mcg}$ & - & $25 \mathrm{mcg}$ & 1,000 mcg & - & - & - & $100 \mathrm{mcg}$ \\
\hline Riboflavin & $1.3 \mathrm{mg}$ & $100 \mathrm{mg}$ & - & - & $1.7 \mathrm{mg}$ & $1 \mathrm{mg}^{+}$ & $1.3 \mathrm{mg}$ & $20 \mathrm{mg}$ & - & $1.7 \mathrm{mg}$ & - & - & - & $8 \mathrm{mg}$ & $1 \mathrm{mg}$ & - & $25 \mathrm{mg}$ & - & - & - & $5 \mathrm{mg}$ & $6 \mathrm{mg}$ \\
\hline Niacin & $14 \mathrm{mg}$ & $35 \mathrm{mg}$ & - & - & $20 \mathrm{mg}$ & $20 \mathrm{mg}$ & $16 \mathrm{mg}$ & $20 \mathrm{mg}$ & - & $20 \mathrm{mg}$ & - & - & - & $15 \mathrm{mg}$ & $2 \mathrm{mg}^{+}$ & - & $25 \mathrm{mg}$ & - & - & $10 \mathrm{mg}^{\dagger}$ & $18 \mathrm{mg}$ & $20 \mathrm{mg}$ \\
\hline Pantothenic acid & $5 \mathrm{mg}$ & NE & - & - & $10 \mathrm{mg}$ & - & $5 \mathrm{mg}$ & $10 \mathrm{mg}$ & - & $10 \mathrm{mg}$ & - & - & - & - & $2 \mathrm{mg}^{+}$ & - & $25 \mathrm{mg}$ & - & - & - & $10 \mathrm{mg}$ & $10 \mathrm{mg}$ \\
\hline Vitamin B6 & $1.3 \mathrm{mg}$ & $100 \mathrm{mg}$ & - & $2 \mathrm{mcg}^{+}$ & $2 \mathrm{mg}$ & - & $1.3 \mathrm{mg}$ & $20 \mathrm{mg}$ & - & $2 \mathrm{mg}$ & - & $2 \mathrm{mg}$ & - & $1.4 \mathrm{mg}$ & $1 \mathrm{mg}^{+}$ & $30 \mathrm{mg}$ & $25 \mathrm{mg}$ & - & - & - & $10 \mathrm{mg}$ & $6 \mathrm{mg}$ \\
\hline Biotin & $30 \mathrm{mcg}$ & $550 \mathrm{mcg}$ & - & - & - & - & $300 \mathrm{mcg}$ & - & - & $300 \mathrm{mcg}$ & - & - & - & - & $40 \mathrm{mcg}$ & - & $150 \mathrm{mcg}$ & - & - & - & $150 \mathrm{mcg}$ & $100 \mathrm{mcg}$ \\
\hline Vitamin C & $90 \mathrm{mg}$ & $2,000 \mathrm{mg}$ & $500 \mathrm{mg}$ & $120 \mathrm{mg}$ & $250 \mathrm{mg}$ & $200 \mathrm{mg}$ & $100 \mathrm{mg}$ & $60 \mathrm{mg}^{+}$ & $100 \mathrm{mg}$ & $60 \mathrm{mg}^{\dagger}$ & - & $120 \mathrm{mg}$ & - & $80 \mathrm{mg}^{+}$ & $60 \mathrm{mg}^{+}$ & - & $120 \mathrm{mg}$ & $500 \mathrm{mg}^{\dagger}$ & - & - & $90 \mathrm{mg}$ & $250 \mathrm{mg}$ \\
\hline Vitamin D & $600 \mathrm{IU}$ & 4,000 IU & 1,000 IU & - & $4001 \mathrm{U}^{+}$ & - & $200 \mathrm{IU}^{+}$ & $400 \mathrm{IU}^{+}$ & - & - & - & - & - & - & 1,000 IU IU & - & $8001 \mathrm{IU}$ & - & - & - & $6001 \mathrm{IU}$ & $1,0001 \mathrm{IU}$ \\
\hline Vitamin E & зз Іи & 1,100 IU & $400 \mathrm{IU}$ & $15 \mathrm{mg}^{+}$ & 150110 & 40 IU & $45 \mathrm{IU}$ & $30 \mathrm{lU}^{+}$ & $4001 \mathrm{IU}$ & $30 \mathrm{IU}^{+}$ & 54 IU & $100 \mathrm{mg}$ & & $12 \mathrm{mg}^{\dagger}$ & $2 \mathrm{IU}^{+}$ & - & $100 \mathrm{IU}$ & $100 \mathrm{IU}$ & 6014 & - & $30 \mathrm{mg}$ & $30 \mathrm{IU}$ \\
\hline Vitamin K & $120 \mathrm{mg}$ & NE & - & - & $80 \mathrm{mcg}^{+}$ & - & - & $200 \mathrm{mg}$ & - & - & - & - & - & - & $70 \mathrm{mcg}^{\dagger}$ & - & $100 \mathrm{mcg}^{+}$ & - & - & - & - & - \\
\hline Zinc & $11 \mathrm{mg}$ & $40 \mathrm{mg}$ & $20 \mathrm{mg}$ & $15 \mathrm{mg}$ & $30 \mathrm{mg}$ & $15 \mathrm{mg}$ & $15 \mathrm{mg}$ & $15 \mathrm{mg}$ & $25 \mathrm{mg}$ & $15 \mathrm{mg}$ & - & $15 \mathrm{mg}$ & - & $15 \mathrm{mg}$ & $1 \mathrm{mg}^{+}$ & $30 \mathrm{mg}$ & $20 \mathrm{mg}$ & $15 \mathrm{mg}$ & $30 \mathrm{mg}$ & $7.5 \mathrm{mg}$ & $15 \mathrm{mg}$ & $22.5 \mathrm{mg}$ \\
\hline
\end{tabular}

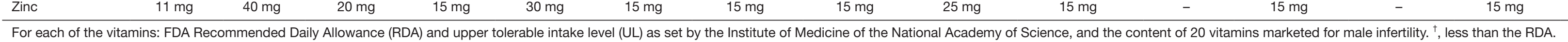

